\author{
Research Article \\ www.ijrap.net
}

\title{
A COMPARATIVE STUDY OF DIET AND GUDA PIPPALIMULA YOGA IN THE MANAGEMENT OF NIDRANASHA (PRIMARY INSOMNIA)
}

Kavitha S. ${ }^{1}$, Akhilesh Shukla ${ }^{2 *}$, T. Sundar Raj Perumall ${ }^{3}$, Bala Krishna D. L. ${ }^{4}$

${ }^{1}$ Reader, Department of Kriya Sharira, Karnataka Ayurveda College, Mangalore, Karnataka, India

${ }^{2}$ Lecturer, Department of Samhita and Siddhanta, Govt. Ayurveda College, Bilaspur, Chhattisgarh, India

${ }^{3}$ Chief Physician and Director, Arogyadhatri Ayurveda Speciality Centre, Murali Nagar, Vizag, Andhra Pradesh, India

${ }^{4}$ Professor, Department of Panchakarma, Govt. Ayurveda Medical College, Mysore, Karnataka, India

Received on: 17/04/17 Accepted on: 14/05/17

\author{
*Corresponding author \\ E-mail: an2akhilesh@gmail.com
}

DOI: 10.7897/2277-4343.082103

\begin{abstract}
Nidra (sleep) is considered as one of the subsidiary pillars of healthy life along with Ahara (diet) and Brahmcharya (celibacy). Insomnia has become a major health hazard, drawing the attention of professionals and researchers all over the world. The conventional approach to management of Primary insomnia includes antidepressants, sedatives, tranquilizers, hypnotic drugs, etc. but safety of these drugs is the matter of concern among physicians. A Comparative Single Blind Clinical Study with pre and post design was planned. The patients were divided in to three Groups consisting of 15 in each. Group 'A' was treated with $2 \mathrm{~g}$ Pippalimula Choorna (root powder of Piper longum Linn.) along with $2 \mathrm{~g}$ of Guda (Jaggery) with milk, in the evening after meals; along with classical diet chart for Nidranasha, Group ' $\mathrm{B}$ ' - $2 \mathrm{~g}$ Pippalimula Choorna along with $2 \mathrm{~g}$ of Guda with milk, in the evening after meals and Group ' $\mathrm{C}$ ' was only advised to follow diet chart, for a period of 48 days. The follow up period was kept for 48 days. All the patients showed improvement in all the parameters in all the three groups. However, in groups 'A' and 'B' the improvement was highly significant. Changes within the group were also found to be highly significant. Guda-Pippalimula Yoga along with Ayurvedic diet plan was found to be very effective in the management of Nidranasha (primary insomnia).
\end{abstract}

Keywords: Nidranasha, primary insomnia, Guda-Pippalimula

\section{INTRODUCTION}

Our treatises emphasized the importance of Trayopastambhas viz. Aahara (food), Nidra (sleep) and Brahmacharya (celibacy) as the subsidiary pillars of a healthy life ${ }^{1}$. Nidra is the most neglected part of modern lifestyle where one gives least importance to the timing, duration, and quality of sleep with stress playing an important role in inducing insomnia. The condition of insomnia may not be a life threatening illness, but it has a tendency to damage the person's daily life, including his social and occupational life. If it is very chronic, the person may develop varieties of psychiatric illness also. Considering this, insomnia is considered to be a major health hazard, drawing the attention of professionals and researchers all over the world. The diagnostic criteria for primary insomnia include: ${ }^{2}$ Difficulty initiating or maintaining sleep or non-restorative sleep, causing clinically significant distress or impairment in social, occupational, or other important areas of functioning, not occurring exclusively during the course of another sleep disorder and not due to the direct physiological effects of a substance or a medical condition. Primary Insomnia, where the cause of sleeplessness is obscure, is normally treated with antidepressant drugs, sedatives, tranquilizers and hypnotic drugs etc. But these drugs may lead to many complications such as hangover, tolerance towards the drug, reoccurrence of the symptoms on the withdrawal of the drug, etc. Other modalities of treatment such as relaxation therapy and psychotherapy also have their limitations. Holistic management of Nidranasha is the need of the day and Ayurvedic professionals need to re-evaluate the management of Nidranasha. Nidranasha is not explained as a separate disease in any of classical text books of Ayurveda but the descriptions are available in various contexts like Vataja Nanatmaja Vikaras (diseases exclusively produced due to Vata Dosha), Vataja Jwara (fever of Vata origin), Vataja Hridroga (cardiac ailment due to Vata) etc. Various drugs are also mentioned to be highly effective in Nidranasha. Diet and lifestyle modifications have a great role to play in assisting patients of primary insomnia as per our treatises. GudaPippalimula yoga was indicated in the management of Nidranasha in the texts Bhaishajya Ratnavali ${ }^{3}$ and Bhavaprakasha ${ }^{4}$, so the study was undertaken to evaluate the efficacy of Guda-Pippalimula Yoga in the management of Nidranasha. A large group of Ahara Dravyas (food items) are mentioned in various classics which are useful in promoting sleep. So a diet chart was prepared using the references with an intention of relieving insomnia with a healthy diet. The duration of study was one Mandala (48 days). Pittsburg sleep Quality Index was used to assess the effect of study before and after the treatment. Post therapy follow-up was conducted after 48 days.

\section{Aims and objectives}

To clinically evaluate the efficacy of Guda-Pippalimula Yoga in Nidranasha (Primary Insomnia) by comparing with Ayurvedic diet suggested in Nidranasha (Primary Insomnia)

\section{MATERIAL AND METHODS}

A comparative single blind clinical study with pre and post design was planned. Purposive sampling was done. 45 patients coming under inclusion criteria approaching to the OPD of the Government Ayurveda Medical College \& Hospital, Mysore during the period $2009-10$ were selected for the study. The 
clinical trial was done as part of the post graduate thesis, after getting approval from the institute and the consent from the patients were obtained as per Helsinki declaration.

\section{Inclusion Criteria}

Patients of either sex between the age group of 30-50 years with symptoms of primary insomnia as per APA (American Psychiatric Association) Diagnostic and Statistical Manual of Mental Disorders: DSM-IV; 4th ed. with a history of one to five years were selected for this study

\section{Exclusion Criteria}

Patients suffering from other systemic illnesses and on any medication, who have undergone any surgery within the past 6 months and insomnia with a history of more than five years were excluded from the study.

\section{Diagnostic Criteria}

Normal sleep pattern-

- 6-8 hours of sleep will be considered as normal sleep.

- 15-30 minutes of duration to initiate the sleep without any disturbances will be considered as normal.

Abnormal sleep pattern

- If the patient is having difficulty in initiating sleep even after one hour.

- Reduction in sleep time for more than two hours.

- Discontinuation of sleep for at least two to three times.

\section{Sampling Method}

Purposive sampling was done. 45 patients coming under inclusion criteria approaching the OPD \& IPD of Government Ayurveda Medical College \& Hospital, Mysore and special camps conducted in and around Mysore were selected for the study.

\section{Intervention}

After the Diagnosis, the selected patients were assigned to identical group of 15 patients in each of the 3 Groups. This is a single blind comparative clinical study. All the patients were treated on O.P.D basis only and pre-treatment, post-treatment and post follow-up readings were noted to assess various parameters of this study

Group A: 2g Pippalimula Choorna along with $2 \mathrm{~g}$ of Guda was administered with milk, in the evening after meals; along with advised to follow the diet chart for Nidranasha created as per our classics, for a period of 48 days.

Group B: 2g Pippalimula Choorna along with 2g of Guda was administered with milk, in the evening after meals, for a period of 48 days.

Group C: Only advised to follow the diet chart for Nidranasha created as per our classics, for a period of 48 days.

The follow up period was kept for 48 days.

\section{Parameters of the study}

Pittsburgh Sleep Quality Index (PSQI) was used to assess the effect of study before and after the treatment. The Pittsburgh Sleep Quality Index (PSQI) ${ }^{5}$ was developed to measure sleep quality during the previous month and to discriminate between good and poor sleepers. The covered domains include subjective sleep quality, sleep latency, sleep duration, habitual sleep efficiency, sleep disturbances, Use of sleep medications, and daytime dysfunction. The PSQI generates seven scores that correspond to the domains listed previously. Each component score ranges from 0 (no difficulty) to 3 (severe difficulty). The component scores are summed to produce a global score (range of 0-21). A PSQI global score $>5$ is considered to be suggestive of significant sleep disturbance.

\section{Statistical Analysis}

Statistical analysis to assess individual and comparative effects of the groups was done using Chi- Square test, One Sample ttest, Contingency Co-efficient Test and Repeated Measures ANOVA. Analysis was considered by SPSS for windows (Statistical presentation system software) version 14 developed by SPSS, New York (2005).

\section{OBSERVATIONS AND RESULTS}

Total 45 patients coming under the inclusion criteria were selected for the clinical study and divided into three groups. Observations related to principle variables viz: age, gender, marital status, religion, habitat, education, occupation, nature of work, socio-economic status, chronicity, diet, habits, Prakriti (physical constitution), onset are shown in table 1., results about the mean global PSQI values in group $\mathrm{A}, \mathrm{B}$ and $\mathrm{C}$ shown in table 2, and general linear model-descriptive statistics of global PSQI score is shown in table no. 3, tests of within-subjects effects for global PSQI shown in table 4 , table 5 showing PSQI domains which include subjective sleep quality, sleep latency, sleep duration, habitual sleep efficiency, sleep disturbances, use of sleep medications, and daytime dysfunction. The diet chart which was used for group A and $\mathrm{C}$ is shown in table 6 .

Table 1: General Observation $(n=45)$

\begin{tabular}{|l|l|l|l|}
\hline Character & Categories & Number of patients & Percentage \\
\hline \multirow{3}{*}{ Age } & $30-40$ years & 15 & 33.3 \\
\cline { 2 - 4 } & $41-50$ years & 30 & 66.7 \\
\hline \multirow{3}{*}{ Gender } & Male & 14 & 31.1 \\
\cline { 2 - 4 } & Female & 31 & 68.9 \\
\hline \multirow{5}{*}{ Religion } & Married & 33 & 73.3 \\
\cline { 2 - 4 } & Unmarried & 5 & 11.1 \\
\cline { 2 - 4 } & Widow & 7 & 15.6 \\
\cline { 2 - 4 } & Hindu & 38 & 84.5 \\
\cline { 2 - 4 } & Muslim & 5 & 11.1 \\
\cline { 2 - 4 } & Christian & 1 & 2.2 \\
\cline { 2 - 4 } & Jain & 1 & 2.2 \\
\hline
\end{tabular}




\begin{tabular}{|c|c|c|c|}
\hline \multirow[t]{2}{*}{ Habitat } & Rural & 11 & 24.5 \\
\hline & Urban & 34 & 75.5 \\
\hline \multirow[t]{6}{*}{ Education } & Uneducated & 13 & 28.9 \\
\hline & Primary & 7 & 15.5 \\
\hline & Secondary & 18 & 28.9 \\
\hline & Higher secondary & 18 & 40.0 \\
\hline & Graduate & 4 & 8.9 \\
\hline & Post Graduate & 3 & 6.7 \\
\hline \multirow[t]{5}{*}{ Occupation } & House wife & 30 & 66.7 \\
\hline & Salesman & 3 & 6.7 \\
\hline & Govt. employee & 2 & 4.4 \\
\hline & Teacher & 4 & 8.9 \\
\hline & Mason & 1 & 2.2 \\
\hline \multirow[t]{2}{*}{ Nature of work } & Active & 25 & 55.6 \\
\hline & Sedentary & 20 & 44.5 \\
\hline \multirow[t]{3}{*}{ Socio-Economic Status } & Poor & 20 & 35.5 \\
\hline & Lower Middle & 25 & 55.5 \\
\hline & Upper Middle & 4 & 8.9 \\
\hline \multirow[t]{2}{*}{ Chronicity } & $12-24$ months & 33 & 73.3 \\
\hline & $25-60$ months & 12 & 26.7 \\
\hline \multirow[t]{2}{*}{ Diet } & Vegetarian & 18 & 40.0 \\
\hline & Vegetarian + Non vegetarian & 27 & 60.0 \\
\hline \multirow[t]{5}{*}{ Habits } & No Habits & 1 & 2.2 \\
\hline & Tea & 16 & 35.6 \\
\hline & Coffee & 18 & 40.0 \\
\hline & Tea + Coffee & 9 & 20.0 \\
\hline & Tea, Cigarette, Alcohol & 1 & 2.2 \\
\hline \multirow[t]{3}{*}{ Prakriti (physical constitution) } & Vata-Pitta & 28 & 62.2 \\
\hline & Pitta-Kapha & 2 & 4.4 \\
\hline & Kapha-Pitta & 15 & 33.4 \\
\hline \multirow[t]{3}{*}{ Agni (Digestive capacity) } & $\begin{array}{l}\text { Samagni (normal digestive } \\
\text { capacity) }\end{array}$ & 33 & 73.4 \\
\hline & $\begin{array}{l}\text { Mandagni (weak digestive } \\
\text { capacity) }\end{array}$ & 7 & 15.5 \\
\hline & $\begin{array}{ll}\text { Vishamagni } & \text { (fluctuating } \\
\text { digestive capacity) } & \\
\end{array}$ & 5 & 11.1 \\
\hline \multirow[t]{2}{*}{ Onset } & Gradual & 20 & 44.4 \\
\hline & Sudden & 25 & 55.6 \\
\hline
\end{tabular}

Table 2: Mean Global PSQI values in Group A, B and C

\begin{tabular}{|l|l|l|l|}
\hline Group & Before Treatment & After Treatment & After Follow-up \\
\hline Group A & 16.67 & 5.73 & 8.73 \\
\hline Group B & 16.87 & 6.53 & 10.73 \\
\hline Group C & 17.47 & 10.20 & 14.73 \\
\hline Total & 17 & 7.49 & 11.40 \\
\hline
\end{tabular}

Table 3: General Linear Model-Descriptive Statistics of Global PSQI score

\begin{tabular}{|l|l|l|l|l|}
\hline & GROUP & Mean & Std. Deviation & N \\
\hline \multirow{4}{*}{ PSQI } & BT & 16.67 & 2.024 & 15 \\
\cline { 2 - 5 } & Group A & 16.87 & 1.959 & 15 \\
\cline { 2 - 5 } & Group C & 17.47 & 1.598 & 15 \\
\cline { 2 - 5 } & Total & 17.00 & 1.859 & 45 \\
\hline \multirow{3}{*}{ PSQI } & Group A & 5.73 & 2.052 & 15 \\
\cline { 2 - 5 } & Group B & 6.53 & 2.134 & 15 \\
\cline { 2 - 5 } & Group C & 10.20 & 3.913 & 15 \\
\cline { 2 - 5 } & Total & 7.49 & 3.395 & 15 \\
\hline \multirow{3}{*}{ PSQI } & Group A & 9.67 & 2.845 & 45 \\
\cline { 2 - 5 } & Group B & 10.73 & 3.494 & 15 \\
\cline { 2 - 5 } & Group C & 14.73 & 2.890 & \\
\cline { 2 - 5 } & Total & 11.71 & 3.739 & \\
\hline
\end{tabular}

Table 4: Tests of Within-Subjects Effects for Global PSQI

\begin{tabular}{|l|l|l|l|l|l|}
\hline Source & Type III Sum of Squares & df & Mean Square & F & Sig. \\
\hline Change & 2043.911 & 2 & 1021.956 & 219.938 & .000 \\
\hline Change * Group & 90.444 & 4 & 22.611 & 4.866 & .001 \\
\hline Error (Change) & 390.311 & 84 & 4.647 & & \\
\hline
\end{tabular}


Table 5: PSQI domains which include subjective sleep quality, sleep latency, sleep duration, habitual sleep efficiency, sleep disturbances, use of sleep medications, and daytime dysfunction

\begin{tabular}{|c|c|c|c|c|c|c|c|c|}
\hline \multirow[t]{2}{*}{ Component } & \multirow[t]{2}{*}{ Group } & \multirow{2}{*}{$\begin{array}{l}\text { Before } \\
\text { treatment }\end{array}$} & \multirow{2}{*}{$\begin{array}{l}\text { After } \\
\text { Treatment }\end{array}$} & \multirow{2}{*}{$\begin{array}{l}\text { After } \\
\text { Follow up }\end{array}$} & \multicolumn{4}{|c|}{ Symmetric Measures in Component } \\
\hline & & & & & \multirow{22}{*}{ Nominal } & \multirow{22}{*}{$\begin{array}{l}\text { Contingency } \\
\text { Coefficient }\end{array}$} & Value & Approx. Sig \\
\hline \multirow{3}{*}{$\begin{array}{l}\text { Subjective sleep } \\
\text { quality }\end{array}$} & $\mathrm{A}$ & 2.4 & 0.53 & 1.27 & & & .709 & .000 \\
\hline & $\mathrm{B}$ & 2.4 & 0.67 & 1.33 & & & 670 & .000 \\
\hline & $\mathrm{C}$ & 2.47 & 1.20 & 1.87 & & & .581 & .001 \\
\hline \multirow[t]{3}{*}{ Sleep latency } & $\mathrm{A}$ & 3 & 1.27 & 2.07 & & & .682 & .000 \\
\hline & $\mathrm{B}$ & 3 & 1.20 & 2.20 & & & .646 & .000 \\
\hline & $\mathrm{C}$ & 3 & 1.87 & 2.67 & & & .584 & .001 \\
\hline \multirow[t]{3}{*}{ Sleep duration } & $\mathrm{A}$ & 2.8 & 1.13 & 1.53 & & & .693 & .000 \\
\hline & $\mathrm{B}$ & 2.8 & 1.13 & 1.53 & & & .641 & .000 \\
\hline & $\mathrm{C}$ & 2.93 & 1.53 & 2.60 & & & .558 & .002 \\
\hline \multirow[t]{3}{*}{ Sleep efficiency } & $\mathrm{A}$ & 2.73 & 0.60 & 1.53 & & & .637 & .000 \\
\hline & $\mathrm{B}$ & 2.67 & 0.87 & 1.80 & & & .617 & .000 \\
\hline & $\mathrm{C}$ & 3.0 & 2.13 & 2.67 & & & .453 & .071 \\
\hline \multirow[t]{3}{*}{ Sleep disturbance } & $\mathrm{A}$ & 1.87 & 1,0 & 1.27 & & & .566 & .000 \\
\hline & $\mathrm{B}$ & 1.67 & 1.13 & 1.47 & & & .372 & .124 \\
\hline & $\mathrm{C}$ & 1.73 & 1.40 & 1.53 & & & .274 & .455 \\
\hline \multirow{3}{*}{$\begin{array}{l}\text { Use of sleep } \\
\text { medication }\end{array}$} & $\mathrm{A}$ & 2.47 & 0.67 & 1.27 & & & .697 & .000 \\
\hline & $\mathrm{B}$ & 2.67 & 0.73 & 1.40 & & & .703 & .000 \\
\hline & $\mathrm{C}$ & 2.67 & 1.27 & 2.13 & & & .626 & .000 \\
\hline \multirow{3}{*}{$\begin{array}{l}\text { Daytime } \\
\text { dysfunction }\end{array}$} & $\mathrm{A}$ & 1.33 & 0.53 & 0.80 & & & .537 & .001 \\
\hline & $\mathrm{B}$ & 1.80 & 0.73 & 0.93 & & & .629 & .000 \\
\hline & $\mathrm{C}$ & 1.67 & 0.80 & 1.20 & & & .560 & .002 \\
\hline
\end{tabular}

Table 6: Diet chart given to the Groups A and C

\begin{tabular}{|l|l|l|}
\hline Sl. NO. & Time & Diet \\
\hline 1 & $6.00 \mathrm{AM}$ & One glass of Milk $\{150 \mathrm{ml}\}$ with, molasses. \\
\hline 2 & 8.00 AM & Chapati/Poori/Idli/Dosa/Uddin Vada (prepared from black gram)/Paratha with ghee/wheat Upma with Ghee \\
\hline 3 & $11.00 \mathrm{AM}$ & Sugarcane juice/grape juice \\
\hline 4 & $1.00 \mathrm{PM}$ & $\begin{array}{l}\text { Shastika Shali rice with curd and curry prepared from fish, prawns, chicken, mutton, beef, onion, sesame. } \\
\text { Sweet prepared from milk, jaggery, wheat, black gram laddu }\end{array}$ \\
\hline 5 & $4.00 \mathrm{PM}$ & Sweet lassi /sugar cane juice/grape juice/ \\
\hline 6 & $7.30 \mathrm{PM}$ & $\begin{array}{l}\text { Chapati or Paratha with ghee and curry prepared from fish, prawns, chicken, mutton, Beef, Pork, onion, } \\
\text { Sesame and Curd. }\end{array}$ \\
\hline 7 & $9.30 \mathrm{PM}$ & One glass of milk $\{150 \mathrm{ml}\}$ with jaggery \\
\hline
\end{tabular}

\section{DISCUSSION}

\section{Age}

In the present study, $15(33.3 \%)$ patients were in the age group of $30-40,30$ patients $(66.7 \%)$ were in the age group of $41-50$. The age in relation with Nidranasha is statistically insignificant. This might be because of smaller sample size.

\section{Gender}

In the present study, 14 patients $(31.1 \%)$ were males \& 31 patients $(68.9 \%)$ were females. This is statistically significant ( $p$ value $=0.040$ ) indicating more prevalence of Nidranasha among females.

\section{Marital Status}

In the present study, 33 patients $(73.3 \%)$ were married, 5 patients $(11.1 \%)$ were unmarried \& 7 patients $(15.6 \%)$ were widowers. This is statistically insignificant $(\mathrm{p}$ value $=.139)$ indicating more prevalence of Nidranasha in married people. Marital troubles might account for stress which might have induced sleeplessness

\section{Religion}

In the present study, 38 patients $(84.5 \%)$ were Hindu, 5 patients $(11.1 \%)$ were Muslim, 1 patient $(2.2 \%)$ was Christian \&
1 patient $(2.2 \%)$ was Jain. This is statistically insignificant ( $\mathrm{p}$ value $=.320$ ) indicating more prevalence of Nidranasha in Hindus which might be only because of more Hindu population followed by Muslims in and around Mysore area.

\section{Habitat}

In the present study, 11 patients $(24.5 \%)$ were rural, 34 patients $(75.5 \%)$ were urban. This is statistically significant ( $\mathrm{p}$ value $=0.040$ ) indicating more prevalence of Nidranasha in Urban people which indicates that the effect of urban living under stressful conditions and pollution causes more prevalence of Nidranasha in urban people when compared with rural people.

\section{Occupation}

In the present study, 2 patients $(4.4 \%)$ were agriculturists, 3 patients $(6.7 \%)$ were shop-keepers, 30 patients $(66.7 \%)$ were house-wives, 3 patients $(6.7 \%)$ were salesman, 2 patients $(4.4 \%)$ were govt. officials, 4 patients $(8.9 \%)$ were teachers \& 1 patient $(2.2 \%)$ was a mason. This is statistically insignificant ( $p$ value $=0.625$ ). More prevalence of Nidranasha in housewives however cannot be attributed to a specific reason and a study on a larger sample gives a better picture. 


\section{Socio-Economic Status}

In the present study, 16 patients were poor (35.5\%), 25 patients (55.6\%) belonged to the lower middle class and 4 patients $(8.9 \%)$ belonged to the upper middle class. This is statistically insignificant ( $\mathrm{p}$ value $=0.748$ ) indicating more prevalence of Nidranasha in lower middle class. A larger sample study will give better results.

\section{Education}

In the present study, 13 patients $(28.9 \%)$ were illiterate, 7 patients $(15.5 \%)$ had completed their primary education, 18 patients $(40 \%)$ had completed their secondary education, 4 patients $(8.9 \%)$ were graduates and 5 patients $(6.7 \%)$ were postgraduates. This is statistically insignificant ( $p$ value $=0.273$ ) indicating more prevalence of Nidranasha in people who have completed secondary education.

\section{Nature of Work}

In the present study, 25 patients $(55.6 \%)$ were physically active, whereas 20 patients $(44.4 \%)$ had sedentary nature of work. This is statistically insignificant ( $p$ value $=0.914$ ) indicating more prevalence of Nidranasha in people who are active.

\section{Diet}

In the present study, 18 patients $(40 \%)$ consumed vegetarian diet whereas 27 patients $(60.0 \%)$ consumed mixed diet (both vegetarian and non-vegetarian foods). This is statistically highly significant ( $p$ value $=0.000$ ) indicating more prevalence of Nidranasha in people with mixed diet. But according to Ayurveda most of the Ahara suggested for sleeplessness consists of meat of various animals. The cooking style of nonvegetarians by adding a lot of spices and oil to their foods which might cause Vidaha (burning sensation) might result in Nidranasha.

\section{Chronicity}

In the present study, 33 patients $(73.3 \%)$ reported chronicity ranging between 12-24 months, while 12 patients reported chronicity ranging between $25-60$ months. This observation is statistically insignificant ( $\mathrm{p}$ value $=0.256$ )

\section{Prakruti}

In the present study, 28 patients $(62.2 \%)$ were of Vata-Pitta Prakruti, 2 patients (4.4\%) were of Pitta-Kapha Prakruti and 15 patients $(33.4 \%)$ were of Kapha-Vata Prakruti. This is statistically significant $(\mathrm{p}$ value $=0.046)$ indicating more prevalence of Nidranasha in Vata Pitta Prakruti people who might have Vata Pitta Prakopa (aggravation of Vata and Pitta) and Kapha Kshaya (decrease of Kapha) which is the basis for Nidranasha.

\section{Agni}

In the present study, 33 patients had Samagni (73.4\%), 7 patients had Mandagni and 5 patients had Vishamagni (11.1\%). This observation is statistically insignificant $(\mathrm{p}$ value $=0.153$ )

\section{Onset of The Disease}

In the present study, 20 patients $(44.4 \%)$ had Gradual Onset of the disease whereas 25 (63.6) patients had Sudden Onset of the disease. This is statistically significant $(\mathrm{p}$ value $=0.021)$ indicating that some sudden changes in diet or area of work or sleeping place is causing an immediate effect on sleep quality and also causing Nidranasha in many.

Pittsburgh Sleep Quality Index (PSQI) is used to assess the results of the study. PSQI is divided into seven components which indicate seven traits of sleeplessness. They are as follows

\section{Component 1: Subjective sleep quality}

This denotes the rating given by the patient about the quality of his/her sleep during the past month. The results obtained shows that in all the three groups the change was highly significant. However by observing the mean scores we can say that the result is best in Group A followed by Group B and Group C occupies the third place.

\section{Component 2: Sleep latency}

This denotes the time taken by the patient to become asleep after lying down on the bed. The results obtained shows that in all the three groups the change was highly significant. However by observing the mean scores we can say that the group in which time taken to be asleep has reduced significantly is group A followed by Group B and Group C occupies the third place.

\section{Component 3: Sleep duration}

It indicates the number of hours patients are experiencing sleep. The results obtained shows that in all the three groups the change was highly significant. However by observing the mean scores we can say that the group in which sleep duration has increased significantly is group A, followed by Group B, and Group C occupies the third place.

\section{Component 4: Sleep efficiency}

Component 4 indicates the sleep efficiency which can be calculated by dividing the number of actual hours of sleep with number of hours spent in bed multiplied by hundred. Results obtained shows that there is a significant increase in sleep efficiency in both the groups A and B which is highly significant. However in group $\mathrm{C}$ the increase is not statistically significant ( $P$ value 0.071). This shows that intake of Nidrajanaka Ahara (sleep producing diet) only is not sufficient in bringing a statistically significant increase in Sleep Efficiency.

\section{Component 5: Sleep disturbance}

Component 5 indicates Disturbance in sleep during the night in terms of night awakening without any reason or getting up for micturition. Results obtained show that there is a significant decrease in sleep disturbance in group A. It is statistically highly significant. But in group $\mathrm{B}(\mathrm{P}$ value .124) and group $\mathrm{C}(\mathrm{P}$ value $0.455)$ the decrease in sleep disturbance is not significant. However Among $\mathrm{B}$ and $\mathrm{C}$ groups, the average mean scores show that the decrease in sleep disturbance is more in Group B. this observation indicates that to bring a highly significant decrease in sleep disturbance a combination of GudaPippalimula , Nidrajanaka Ahara is very useful.

\section{Component 6: Use of sleep medication}

Component 6 represents the patients need for medication to induce sleep. Results obtained show that in all the three groups there is a significant decrease in the use of sleep medication. It shows that the present study is highly successful in bringing 
down the need for a sleep medication. The statistical values in all the three groups are highly significant. However when we compare the mean scores Group $\mathrm{C}$ in which only Nidrajanaka Ahara was used decrease in score is a bit less.

\section{Component 7: Daytime dysfunction}

Component 7 represents Daytime dysfunction which indicates the patients had trouble staying awake while driving, eating meals, or engaging in social activity during day time or trouble in keeping up enough enthusiasm to get things done. Results show that in groups $\mathrm{A}$ and $\mathrm{C}$ there is a significant decrease in Daytime dysfunction where the result is statistically significant. In group B the decrease in daytime dysfunction is highly significant statistically.

\section{Global PSQI}

Global PSQI score is the sum of all the seven components of PSQI. When we compare the mean values of Group A before Treatment (16.67) After Treatment (5.73) and After follow up (9.67) we observe significant improvement which indicates Guda-Pippalimula Yoga along with a Nidrajanaka diet regimen, helps in producing highly significant improvement in Nidranasha. When we compare the mean values of Group B before Treatment (16.87) After Treatment (6.53) and after follow up (10.73) we observe significant improvement which indicates Guda-Pippalimula Yoga alone is also capable of producing highly significant improvement in Nidranasha. However the mean values indicate that Group A (medicine + diet) is still better than Group B (only medicine). When we compare the mean values of Group $C$ before Treatment (17.47) After Treatment (10.20) and after follow up (14.73) we observe a moderate improvement which indicates Nidrajanaka diet regimen helps in producing moderate improvement in Nidranasha. The change in scores of Global PSQI before the treatment, after the treatment and after follow up is highly significant both in the groups $(\mathrm{P}=0.000)$ and within the groups $(\mathrm{P}=0.001)$.

By comparing the mean values of both the groups, overall effect of group A was found to be better.

\section{Proposed Mode of action of Guda Pippali Mula Yoga}

Guda-Pippalimula Yoga advised in Bhavaprakasha and Bhaishajyaratnavali, with milk as Anupana (after drink) has shown highly significant improvement in the patients of Nidranasha. This action may be due to the synergistic effect of the three ingredients Guda, Pippalimula and milk. Guda with its Madhura Rasa (sweet taste), Madhura Vipaka (sweet at the end of digestion), Guru (heavy) and Snigdha Gunas (unctuous property) ${ }^{6}$ exhibits all the useful properties to promote sleep. However it's Ushna Virya (hot potency) is a debatable property. Though Ushna Virya acts as Vatahara (pacifying Vata) it might also produce Kaphahara (pacifying Kapha) properties. But its effect is being cleverly balanced by the Sheeta Virya (cold potency) of its Anupana (after drink) milk ${ }^{7}$. In the same way Pippalimula with its Katu Rasa (pungent taste), Katu Vipaka (pungent at the end of digestion), Laghu (light) and Tikshna Gunas (sharp properties) ${ }^{8}$ seems to be against the context of Nidra Janakatva (sleep producing) but its Snigdha Guna helps in becoming Vatahara. As Vata vitiation is the most important phase of Nidranasha, Pippalimula might help in the Samprapti Vighatana (breaking the pathogenesis) by virtue of its Vatahara property. Its Anushna Sheeta Virya (slight hot and cold potency) coupled with the properties of milk and jaggery also helps in increasing Kapha and promoting sleep. Milk with its Madhura Rasa, Snigdha, Guru, Mridu (mild), Shlakshna (smooth), Picchila (slimy), Manda (slow) Gunas (properties), Sheeta Virya, Madhura Vipaka, Vatapittahara (pacifying Vata and Pitta) and Sleshmakrit (increasing Kapha) properties milk can act as an excellent adjuvant to Guda and Pippalimula for inducing sleep. And more over buffalo's milk has been regarded as the Agryadravya (leading substance) in promoting sleep 9 . With the above insights we can infer that Guda Pippali Mula Yoga with milk as after drink is a wonderful Yoga containing three potent yet different drugs chosen by our Acharyas which balance each other's' properties in a synergistic fashion to bring about successful promotion of Nidra in Nidranasha patients. Pippalimula has Piperine and Piplartinewhich are known to have sedative effect and are used in epilepsy for its sedative effect ${ }^{10}$, 11 .

\section{CONCLUSION}

On the basis of conceptual Analysis and Observations made in this clinical Study, the following conclusion can be drawn:

Nidranasha effectively represents Insomnia. Increased Vata along with decreased Kapha is the main reason for Nidranasha. It was observed that the primary insomnia is more among the Vata-Pitta Prakruti patients. More patients were from urban areas. Guda-Pippalimula Yoga with milk as after drink is having Vatashamaka (pacifying Vata) and Kapha Vardhaka (increasing Kapaha) property. Diet regimen given to the group also helps in pacifying Vata and increasing Kapha. Individual effect of Group A (Guda-Pippalimula Yoga and diet regimen) is best during all phases of treatment Individual effect of Group B (GudaPippalimula Yoga) is good in all the phases of treatment. Individual effect of Group C (only diet regimen) is not significant during any phase of treatment and during overall intervention. Guda-Pippalimula Yoga with Ksheera Anupana along with a Nidrajanaka (sleep producing) diet regimen is found to be very effective in managing primary insomnia.

For further study, it is recommended that it should be done by taking larger sample for more accurate results and conclusions. For the clinical trial, all types of insomnia can be considered. A study on Insomnia can be done in collaboration with the Sleep laboratory. An attempt has to be made on the effect on Manasika Chikitsa (psychotherapy), such as Ashwasana (counselling) etc., in Nidranasha. The Guda-Pippalimula Yoga, being nonpalatable, could be used in capsule form or any other palatable form (according to convenience).

\section{REFERENCES}

1. Jadavaji Trikamaji Acharya, CharakaSamhita of Agnivesha revised by Charaka and completed by Dridhabala, Sutrasthana Chapter 11, Verse 34-35, Reprint edition, Varanasi, Chaukhamba Orientalia, 2007; p.-74

2. APA (American Psychiatric Association) Diagnostic and Statistical Manual of Mental Disorders: DSM-IV. 4th ed. Washington, DC: American Psychiatric Association

3. Siddhi Nandan Mishra, Bhaishajya Ratnavali of Kaviraj Govind Das Sen, Chap.21, Ver. 10, $1^{\text {st }}$ ed., Varanasi; Choukhamba Surabharati Prakashana, 2013, p. 491

4. Bulusu Sitaram, Bhavaprakasha of Bhavamishra, Madhyamkhanda, Chap.1, Ver. 326, Chowkambha Orientalia, Varanasi, 2010, p: 35

5. Busse DJ, Reynolds CF, Monk TH, Berman SR, Kupfer DJ: The Pittsburg Sleep Quality Index: A new instrument for psychiatric practice and research , Psychiatry Research, 1989, 28:193-213 
6. Bhishagacharya Hari Sadashiva Shastri Paradakara Vaidya , Asthanga Hridayam of Vagbhata, Sutrasthana Chap.5, Ver.47-48 , Chaukhamba Orientalia, Varanasi , 2005; p. 75

7. Jadavaji Trikamaji Acharya, CharakaSamhita of Agnivesha revised by Charaka and completed by Dridhabala, Sutrasthana Chapter 27, Verse 34-35, Reprint edition, Varanasi, Chaukhamba Orientalia, 2007; p.-74.

8. Bhishagacharya Hari Sadashiva Shastri Paradakara Vaidya, Asthanga Hridayam of Vagbhata, Sutrasthana Chap.6, Ver.161-162 , Chaukhamba Orientalia, Varanasi , 2005; p. $-119$

9. Jadavaji Trikamaji Acharya, Charaka Samhita of Agnivesha revised by Charaka and completed by Dridhabala, Sutrasthana Chapter 25, Verse 40, Reprint edition, Varanasi, Chaukhamba Orientalia, 2007; p.-131-132
10. Chauhan Khushbu, Solanki Roshni, Patel Anar, Macwan Carol and Patel Mayuree, Phytochemical and Therapeutic Potential of Piper Longum Linn. A review. Int J. Res. Ayurveda Pharm. 2011,2 (1);p. 157-161

11. P. Manoj, E.V. Soniya, N.S. Banarjee and P. Ravichandran, Recent studies on well-known spice, Piper longum Linn., Natural Product Radiance Vol 3 (4) July- August 2004; p. 222-227

\section{Cite this article as:}

Kavitha $\mathrm{S}$ et al. a Comparative study of diet and guda pippalimula yoga in the management of nidranasha (Primary insomnia). Int. J. Res. Ayurveda Pharm. 2017;8(Suppl 2):155$161 \mathrm{http}: / /$ dx.doi.org/10.7897/2277-4343.082103

\section{Source of support: Nil, Conflict of interest: None Declared}

Disclaimer: IJRAP is solely owned by Moksha Publishing House - A non-profit publishing house, dedicated to publish quality research, while every effort has been taken to verify the accuracy of the content published in our Journal. IJRAP cannot accept any responsibility or liability for the site content and articles published. The views expressed in articles by our contributing authors are not necessarily those of IJRAP editor or editorial board members. 